\title{
Soil Moisture and Aeration Beneath Pervious and Impervious Pavements
}

\author{
Justin Morgenroth and Graeme D. Buchan
}

\begin{abstract}
Pervious paving has been increasingly installed in urban areas as a stormwater management strategy. Pervious pavements exhibit similar strength to impervious analogues, but are highly permeable to air and water. These functional characteristics have led to speculation that pervious paving, used instead of impervious paving, could benefit urban trees. Given that permeability to air and water will have a direct effect on the soil environment, this paper describes research that explores the effect of pervious pavement on underlying soil physical conditions. Results indicate that while soil moisture and aeration dynamics differ greatly beneath paved and unpaved surfaces, differences are usually insignificant between pervious and impervious paving. If urban trees do benefit from overlying pervious paving relative to impervious paving, it is probably not a consequence of soil moisture or aeration. The results challenge existing theories and contribute to the understanding of how pervious pavements affect the moisture and aeration dynamics of underlying soils.

Key Words: Concrete; Permeable; Porous; Road; Sidewalk; Water.
\end{abstract}

Urban areas are characterized by a high concentration of impermeable surfaces; pavements are most pervasive, covering more than half of all land in highly developed urban areas (Ferguson 2005). A recent paradigm shift has resulted in the proliferation of pervious pavements. This is especially true in the United States where the Clean Water Act and other regulations enforced by the Environmental Protection Agency necessitated new methods for stormwater management. These regulations require decreasing surface runoff and treating water at the source, both of which are achieved by pervious pavements.

Though pervious paving is proliferating, research detailing its impact on the surrounding environment is lacking. A number of untested theories are liberally quoted in literature concerning the direct impact of pervious paving on the underlying soil environment, and its indirect effect on urban trees. Tennis et al. (2004) concluded that pervious pavement is "ideal for protecting trees in a paved environment" and Ferguson (2005) suggests that it can "increase the longevity of trees by improving moisture and oxygen relations." Though these sources provide no experimental evidence, their assumptions appear logical as normal tree growth and function require adequate soil water and aeration (Larcher 2003), both of which are allegedly enhanced by pervious pavements.

This paper presents data collected following the first year of a two-year experiment, representing the first phase of a larger experiment. While the overall aim of the research is to better understand the relationship between pervious paving, soil physical conditions, and tree growth, the data presented herein are limited to the effects of overlying pervious pavement on underlying soil. It is expected the permeability of pervious paving, relative to impervious paving, will result in differing soil moisture and aeration dynamics.

\section{METHODS}

\section{Study Site}

The experiment is located on a large parcel of city council land in Christchurch (Lat: 43493'S, Long: 172 $\left.{ }^{\circ} 437^{\prime} \mathrm{E}\right)$, the largest city in New Zealand's South Island. The top meter (3.28 $\mathrm{ft}$ ) of soil is a fine sandy loam (Raeside 1974) overlying a deposit of sand and gravel, a remnant of the alluvial outwash deposited by an ancient glacier (Brown and Weeber 1992).

The climate is temperate, with mean daily maximum temperatures ranging from c. $10^{\circ} \mathrm{C}\left(50^{\circ} \mathrm{F}\right)$ in July, to $21^{\circ} \mathrm{C}\left(70^{\circ} \mathrm{F}\right)$ in January (McGann 1983). Occasional dry northwesterly winds occur during spring and summer, when temperatures can reach $30^{\circ} \mathrm{C}$ $\left(86^{\circ} \mathrm{F}\right)$ and relative humidity can drop to $20 \%-40 \%$ (McGann 1983). Rainfall ranges from $600-700 \mathrm{~mm}$ (24-28 in) annually and is generally evenly distributed throughout the year, with a tendency for slightly higher early winter precipitation (McGann 1983). Uncharacteristically, the summer of 2008 was characterized by intense precipitation. Approximately $15 \%$ of average annual precipitation fell during a single week in February 2008.

\section{Site Preparation and Experimental Design}

In July 2007, the site was cultivated to remove the existing turf and ensure uniform physical conditions to $30 \mathrm{~cm}$ (11.8 in) depth. The mean sampled bulk density following cultivation was 1.26 $\mathrm{Mg} / \mathrm{m}^{3}\left(2123.8 \mathrm{lb} / \mathrm{yd}^{3}\right)$. Given this density, and an estimated particle density of $2.65 \mathrm{Mg} / \mathrm{m}^{3}\left(4466.7 \mathrm{lb} / \mathrm{yd}^{3}\right)$, the total porosity of the soil is c. $52.5 \%$. Following soil preparation, a fully randomized, complete block experiment was installed comprising fifteen plots [each $230 \mathrm{~cm} \times 230 \mathrm{~cm}$ (90.5 in x 90.5 in)] randomly assigned to one of three treatments: 1) Control-the soil was left unpaved and persistent grasses and clover were periodically sprayed with glyphosate and glufosinate-ammonium; 
2) Impervious concrete pavement-a $10 \mathrm{~cm}$ (4 in) deep impervious concrete pad; 3) Pervious concrete pavement-a $10 \mathrm{~cm}$ deep pervious concrete pad. As part of a larger experiment, referred to in the introduction, plane-tree (Platanus orientalis) seedlings were planted in the plot centers and, for pavement treatments, in a circular cut-out (30 cm diameter). As trees contribute significantly to soil moisture dynamics, their presence is crucial for accurately quantifying soil moisture in a simulated urban environment.

\section{Data Collection}

Soil volumetric moisture content $\left(\theta_{\text {soii }}\right)$ was measured every five minutes from December 2007-May 2008, using ECH $\mathrm{O}_{2}$ EC-20 probes (Decagon Devices, Inc., Pullman, WA, U.S.) interfaced with a Campbell CR10X data logger (Campbell Scientific, Inc., Logan, UT, U.S.). Daily means were calculated and weekly means were used to compare differences amongst treatments. The measurement period coincided with early summer to late autumn. Following previous authors (e.g., Baumhardt et al. 2000; Lane and Mackenzie 2001), rather than using the $\mathrm{ECH}_{2} \mathrm{O}$ probe's built-in calibration, the following soil-specific calibration was obtained, using methods recommended by the manufacturer (Cobos 2007):

$$
\theta_{\text {soil }}=1.2447 \cdot \theta_{\text {probe }}+3.5422
$$

Here, $\theta_{\text {soil }}(\%)$ is the calibration-adjusted soil water content, and $\theta_{\text {probe }}(\%)$ is the value predicted by the $\mathrm{ECH}_{2} \mathrm{O}$ probe. By post-processing the data with this calibration, the accuracy of $\theta_{\text {soil }}$ is assured to $\pm 2 \%$ (Decagon Devices Inc. 2006).

In each plot, three probes were buried $5 \mathrm{~cm}(2 \mathrm{in}), 10 \mathrm{~cm}$, and $20 \mathrm{~cm}$ (7.9 in) beneath the soil surface, halfway between the seedling and the plot edge (45 probes in total). Each sensor was inserted parallel to the soil surface, with its flat surface vertical to minimize disturbance of soil moisture movement. The probes were installed in July 2007 and the first readings were collected in December 2007 to allow sufficient time for equilibration.

Four probes temporarily malfunctioned, during which time their readings were discarded. The readings from the remaining four probes, per treatment and depth combination, were used to calculate an average $\theta_{\text {soil }}$ for that combination. The permanent wilting point (PWP) and field capacity (FC) of the soil were measured via pressure plate (Model 150015 bar ceramic plate extractor, Soil Moisture Equipment Corp., Santa Barbara, CA) and a soil moisture release curve. Their values are approximately $11.1 \%$ and $27.9 \%$ respectively, by volume.

Aeration was determined using the steel rod technique (Carnell and Anderson 1986). On December 4, 2007, one steel rod was allocated to each plot and inserted into soils following the method of Hodge et al. (1993). Rods were inserted halfway between the center and edge of each plot. On March 6, 2008, all rods were unearthed, cleaned, and swabbed in an ammonia solution to stop oxidation. Following Carnell and Anderson (1986), two corrosion categories were created: 1 ) red/brown rust or raised black corrosion, which indicated well aerated soil; and 2) smooth black or matte gray corrosion indicative of anaerobic conditions, or shiny metal, both classed as inhospitable for root growth. Using these categories, the corrosion patterns were analyzed and scores reflecting the proportion of rust were assigned to each $12 \mathrm{~cm}$ (4.75 in) segment of rod based on the method of Hodge and Boswell (1993).

\section{Statistical Analyses}

Mean values of weekly volumetric soil moisture were contrasted using one-way analysis of variance (ANOVA), where treatment was the main factor. Two-way ANOVA was used to contrast differences between treatments and depth classes for soil aeration data. Subsequent pairwise comparisons were computed by the Tukey-Kramer HSD test (R Development Core Team 2008). All statistical differences are reported at $P$ value $=0.05$.

\section{RESULTS AND DISCUSSION}

\section{Soil Moisture}

The weekly mean soil moisture values for both pervious and impervious treatments were statistically similar throughout experiment save the final week (measurement days 127-133) when average soil moisture beneath impervious pavement $(32.1 \%)$ was exceeded beneath pervious pavement $(33.8 \%)(P<0.001)$ (Table 1). Both pavement treatments exhibited significantly higher soil moisture values than controls throughout the experiment $(P<0.001)$. While the $\theta_{\text {soil }}$ of unpaved (control) soils ranged from roughly 20\%$32 \%, \theta$ under both pavement treatments steadily declined from over $45 \%$ in early summer to c. $32 \%$ by late autumn (Figure 1).

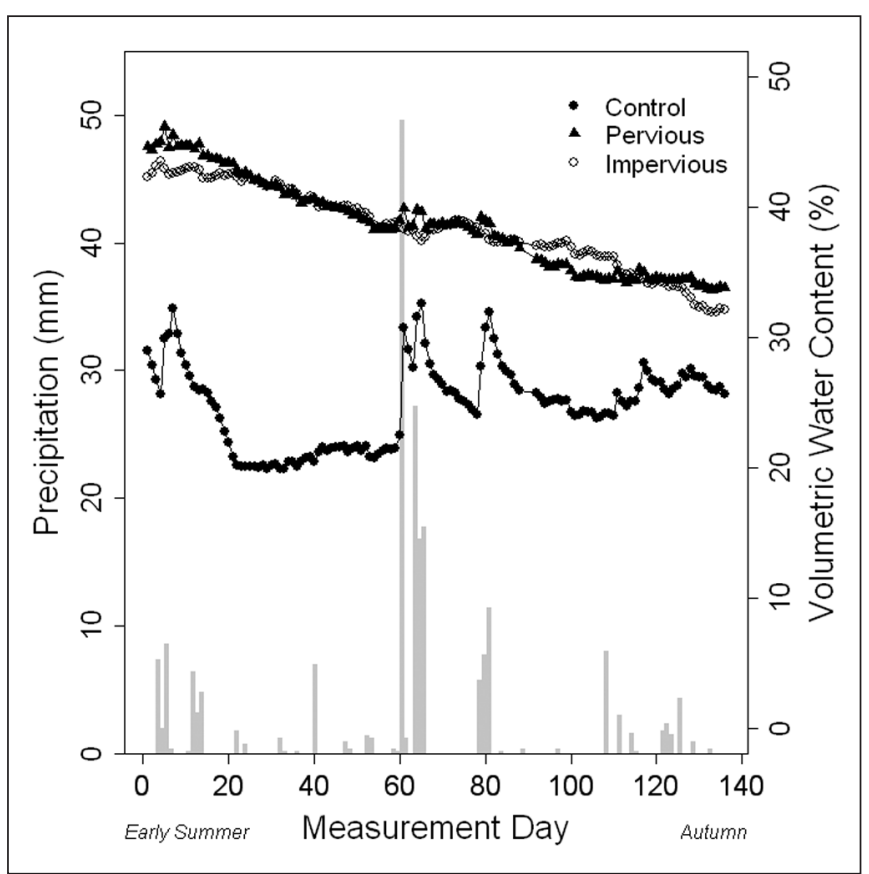

Figure 1. Variations of a) mean daily soil moisture in the uppermost $20 \mathrm{~cm}$ (7.9 in) of soil, and b) daily precipitation.

Two compounding mechanisms likely result in paved soils exhibiting higher $\theta_{\text {soil }}$ than unpaved soils. The first is a distillation process, whereby vapor diffuses towards, then condenses on, a cool surface. Soils gain heat energy and reach their maximum temperature later than maximum air temperature, with a delay between c. 1 hour at the surface to c. 10 hours at $30 \mathrm{~cm}$ depth (Buchan 2001; Celestian and Martin 2004). Following this, they release heat into the atmosphere. In the early evening, as the soil surface cools, water vapor is drawn upwards and condenses on the underside of the pavement then drains back into the uppermost layer of 
Table 1. Weekly volumetric soil moisture for all treatments. Values represent mean measurements in the upper $20 \mathrm{~cm}(8 \mathrm{in})$ of soil. Significant differences resulting from treatment are noted by different symbols following the mean value.

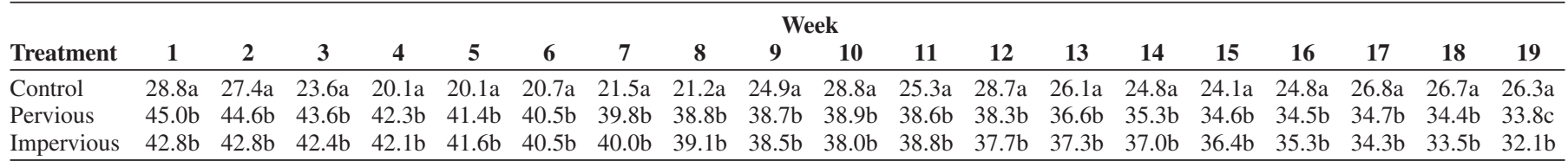

soil. Though distillation also occurs in unpaved soils, there is no barrier to block moisture migration, and the diurnal temperature range of paved soils exceeds unpaved soils (Asaeda and Ca 2000). Thus, distillation is amplified beneath paved surfaces. The second reason for higher soil moisture beneath pavements is that they buffer the soil from atmospheric demand for water, thus minimizing evaporation loss. These two mechanisms likely drive the differences in soil moisture dynamics beneath paved and unpaved surfaces.

A stark contrast between control and pavement treatments is the magnitude of daily $\theta_{\text {soil }}$ fluctuations. It appears that pavement cover buffers underlying soil from rapid fluctuations. Unpaved soils exhibited highly variable $\theta_{\text {soil }}$ increasing sharply in response to precipitation events, then declining due to evapotranspiration and drainage (Figure 1). Fluctuations beneath paving were less pronounced. While $\theta_{\text {soil }}$ beneath impervious paving did not appear to be affected directly by precipitation, $\theta_{\text {soil }}$ beneath pervious paving did exhibit a tempered response to precipitation events (e.g., day 60). Soil moisture loss was also less marked in paved plots. Unpaved sites were subject to water loss through evapotranspiration and drainage, while pavement apparently buffered soils from evaporation, leaving only transpiration and drainage as mechanisms for water loss.

The response of soil moisture at different depths also varied with treatment. In unpaved soils, soil moisture increased predictably with depth (Figure 2). Differences of nearly $10 \%$ often existed between shallow and deeper soil. The seasonal patterns at the three depths were synchronous, but with the magnitudes of the fluctuations shrinking with increasing depth. At $5 \mathrm{~cm}$ depth, $\theta_{\text {soil }}$ fluctuated rapidly, declining to c. $4 \%$ above PWP during prolonged dry periods, but increasing sharply (by up to c. $13 \%$ in a single day) following precipitation.

Generally, soil moisture increased with depth in control plots. During weeks 2-11 (days 8-77) and 13-16 (days 85-112), soil at $5 \mathrm{~cm}$ depth in control plots was significantly dryer than soil in the deeper layers (Table 2). Similarly, during weeks 4, 5, 11, and 1316 , soil at $10 \mathrm{~cm}$ depth was dryer than at $20 \mathrm{~cm}$. These differences appear to express themselves during the drying period following precipitation events. Presumably, evapotranspiration led to the downward movement of a "drying front" (van Keulen and Hillel

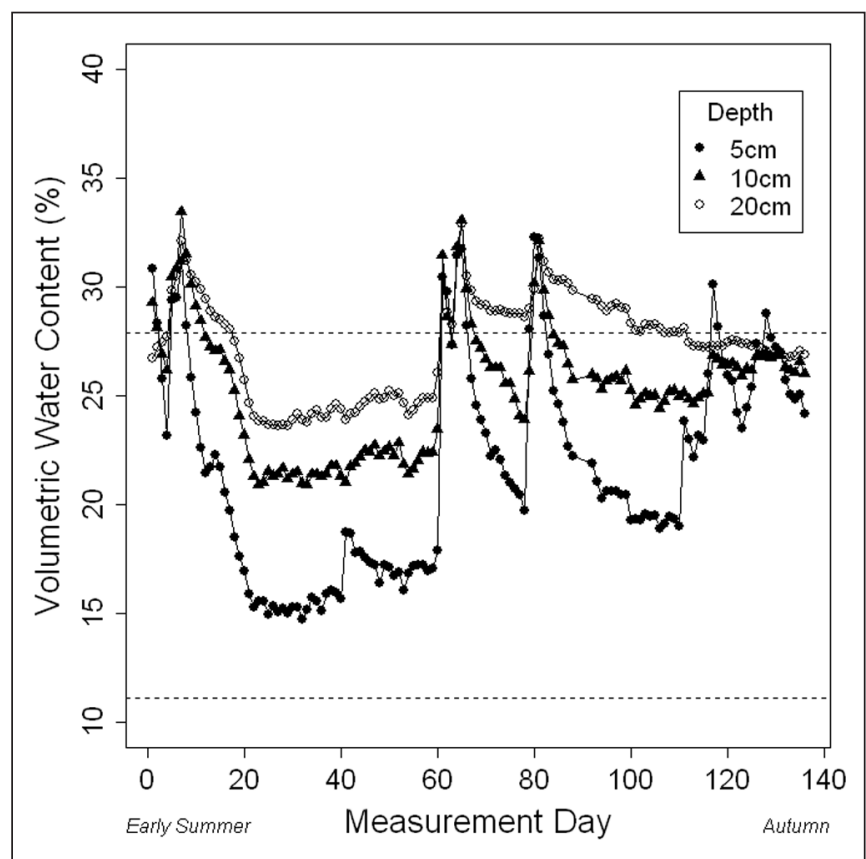

Figure 2. Soil volumetric water content at three depths in unpaved (control) soils. Each data point represents the mean value of five probes (in five replicate plots). The region between the dotted lines represents the least-limiting water range between the field capacity and the permanent wilting point.

1974). Under impervious pavement, soil moisture ranged from c. $32 \%$ to $46 \%$ and the magnitude of single-day $\theta_{\text {soil }}$ fluctuations was low, never exceeding $1 \%$ (Figure 3 ). The variation between depths exceeded $5 \%$ in early summer, but decreased progressively to c. $2 \%$ by early autumn. Despite the measured differences, soil depth was not a significant factor in determining soil moisture content during the great majority of the growing season; the exception was during the final week, when soil at $5 \mathrm{~cm}$ depth was wetter than soil at $20 \mathrm{~cm}$ (Table 1). In spite of this, measured soil moisture was typically lowest at $20 \mathrm{~cm}$ depth and higher in the upper-

Table 2. Weekly mean volumetric soil moisture across different soil depths. Significant differences resulting from soil depth within each treatment and week are noted by different symbols following the mean value. $(P=0.05)$

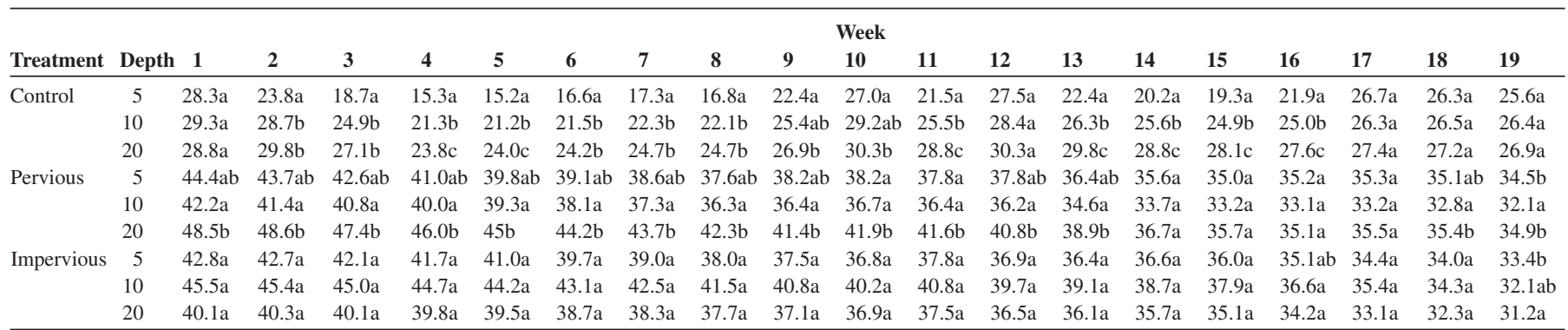


most $10 \mathrm{~cm}$ (3.9 in). It is thought that this may be a reflection of a distillation effect; overnight cooling of pavement draws moisture upwards, thereby maintaining a high $\theta_{\text {soil }}$ in the shallow soil layers.

Soil moisture dynamics beneath pervious paving was more closely related to dynamics beneath impervious paving than to that of exposed soils. Soil moisture ranged from c. $32 \%$ to $50 \%$, and while early summer $\theta_{\text {soil }}$ varied by up to $8 \%$ between different depths, the difference diminished to c. $2 \%-3 \%$ by early autumn (Figure 4). Daily $\theta_{\text {soil }}$ fluctuations were relatively large at shallow depths, often approaching $2 \%$. The magnitude of these fluctuations decreased with depth, presumably due to the buffering effect of overlying soil. Under pervious pavement, $\theta_{\text {soil }}$ was generally similar in the uppermost two layers. However, in the final week (week 19), soil moisture at $5 \mathrm{~cm}$ was significantly greater than at $10 \mathrm{~cm}$ (Table 1). The highest values for $\theta_{\text {soil }}$ were consistently found at $20 \mathrm{~cm}$. At this depth, soils were significantly wetter than soils at $10 \mathrm{~cm}$ for the entire growing season other than a month long period during late summer (weeks 14-17). Interestingly, soil moisture at $5 \mathrm{~cm}$ and $20 \mathrm{~cm}$ were statistically similar, despite measured differences. One explanation for the lowest soil moisture in the middle layer $(10 \mathrm{~cm})$ is that while gravity draws moisture downwards, distillation draws water vapor upwards, thus water is being pulled in both directions by opposing forces.

The measured soil moisture contents beneath both pavement types are extremely high, ranging between c. $4 \%$ and $22 \%$ higher than the FC of the soil throughout the growing season (Figure 3, Figure 4). In fact, soils beneath pavements likely neared saturation for much of the measurement period. Although small increases in $\theta_{\text {soil }}$ beneath pervious paving occurred following precipitation (e.g., days 60,63, and 78), the quick returns to prerainfall levels imply near-saturation and likely drainage into deeper soils. Letey (1985) defined the concept of least-limiting water range (LLWR); this is the soil moisture range within which water, aera-

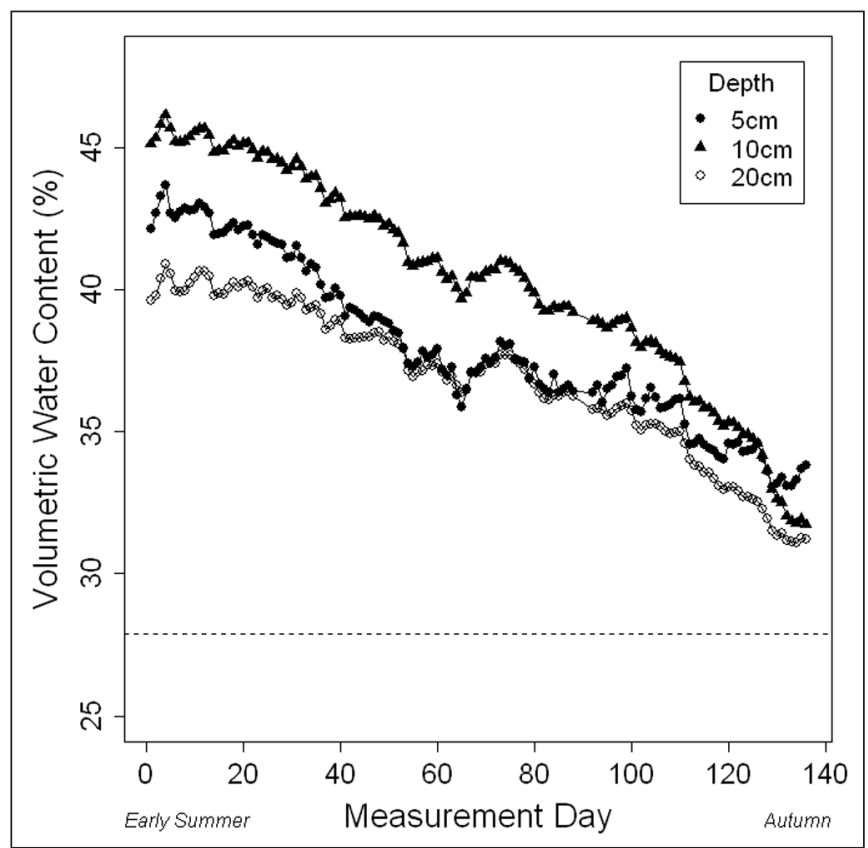

Figure 3. Soil volumetric water content at three depths beneath impervious pavement. Each data point represents the mean value of five probes (in five replicate plots). The dotted line represents the field capacity of the soil. tion, and mechanical resistance do not limit plant growth. The maximum range is bound by the soil's PWP and FC, but can be reduced if aeration or mechanical resistance become limiting. In this experiment, $\theta_{\text {sil }}$ beneath both pavement types rarely fell below $32 \%$ in the upper $20 \mathrm{~cm}$ of soil. Given that the measured FC [0.1bar (1.5 psi) suction] of the soil was $27.9 \%$, the soil moisture beneath both pavements was above the LLWR, and may have limited aeration. In control plots, however, $\theta_{\text {soil }}$ typically fluctuated within the plant-available water bounds of the LLWR, except for temporary rises above $\mathrm{FC}$ following precipitation events. During days 20-60, soil moisture at $5 \mathrm{~cm}$ depth in control plots was generally constant at c. 15\% (Figure 2), near the PWP; however, below $5 \mathrm{~cm} \theta_{\text {soil }}$ increased substantially above the PWP.

Due to the open nature of pervious paving, it was expected that underlying soil moisture would differ compared to soils beneath impervious pavements. However, this was not observed (Table 1). Instead, soil moisture was similar beneath both pavement treatments. Water inputs (rainfall) and outputs (evaporation) were anticipated to be higher in the pervious pavement treatment, but the results challenge these expectations. While increased soil moisture due to rainfall infiltration was observed (e.g., days 60, 63, and 78), soil moisture quickly returned to prerainfall values. So, increased infiltration did not lead to longterm differences between soils beneath pervious and impervious pavements. Due to the already high (near-saturated) soil moisture values below both pervious and impervious paving, these wet soils may not have the ability to retain additional water.

It was assumed the large pores in pervious paving would enable relatively high rates of evaporation. However, such large pores can preclude capillary upflow of water through the pavement (Andersen et al. 1999). As water is limited to the soil/pavement boundary and not the pavement/atmosphere boundary, evaporation is negligible. Together, assumed low evaporation rates and the inability of

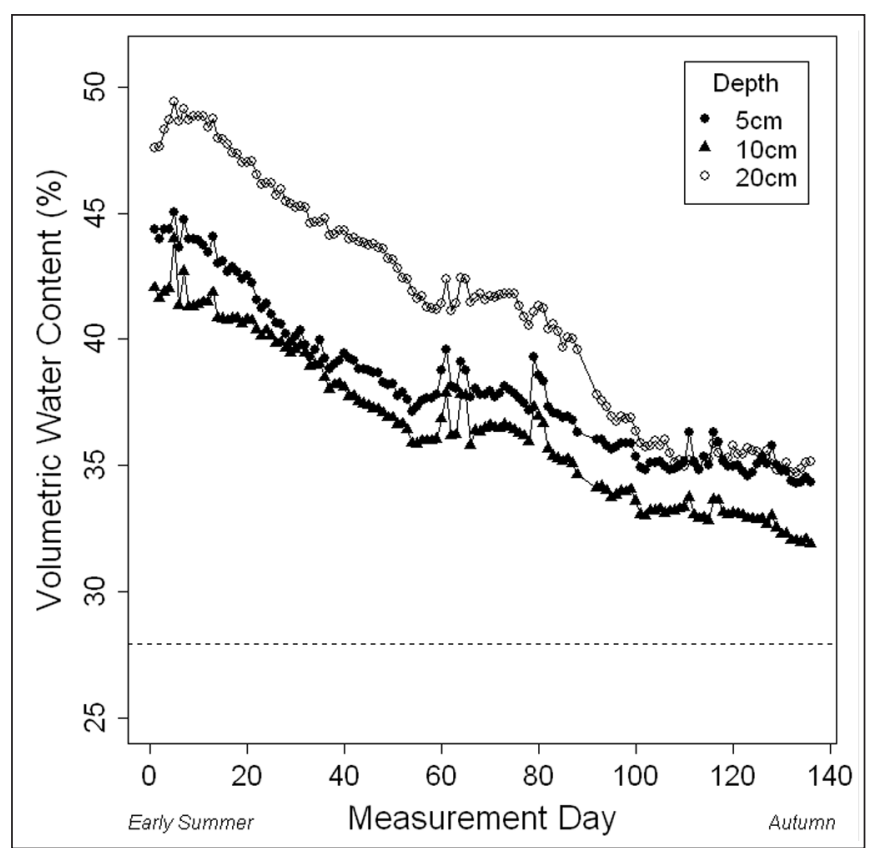

Figure 4. Soil volumetric water content at three depths beneath pervious pavement. Each data point represents the mean value of five probes (in five replicate plots). The dotted line represents the field capacity of the soil. 
already wet soil to retain additional infiltration lead to similar soil moisture contents beneath pervious and impervious pavements.

Given that $\theta_{\text {soil }}$ was consistently above FC beneath paved treatments, it was expected that soil oxygen may have been limited. The presence of smooth black or matte gray oxidation on buried steel rods was an indicator of anaerobic conditions. Rods exhibiting these corrosion patterns received higher anaerobic scores. While anaerobic scores were distinctly lower in unpaved soils than in paved soils (Figure 5), large variation in the data resulted in only a few statistically significant differences (Table 3). The data confirmed that aeration within treatments was independent of soil depth; anaerobic scores were statistically similar throughout the soil profile within all treatments. However, soil aeration did differ among treatments within depth classes. In the uppermost soil layer, anaerobic scores were significantly lower in control plots than in either paved treatment. The only other statistically significant difference occurred in the deepest soil layer where impervious pavement resulted in lower aeration than control plots.

The similarities in aeration beneath both pavement treatments mirrors the observed similarities in $\theta_{\text {soil }}$ (Figure 1), confirming the inverse relationship between air and water occupying the soil pore space. Because oxygen diffuses through air c. 7500 times faster than through water (Feng et al. 2002), this was consistent with the lower degree of corrosion on rods buried beneath pavements.

While paved soils are evidently more poorly aerated, the question of whether or not their aeration is adequate for root respiration is inconclusive. In paved soils, rods were covered by a variegated combination of bright orange and dark corrosion, a pattern representing oxygen concentrations between $2 \%-5 \%$ (Owens et al. 2008), well below the critical limit of $10 \%$ for root function (Glinski and Stepniewski 1985). This suggests that aeration of vir-

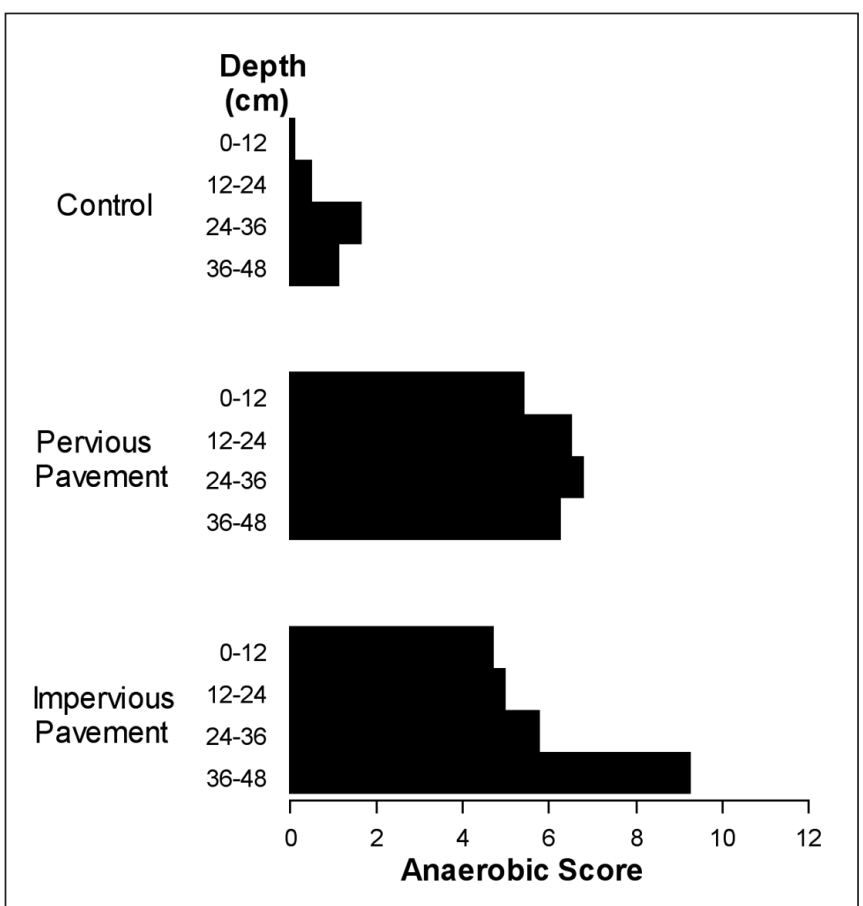

Figure 5. Evaluation of soil aeration. The mean anaerobic score $(n=5)$ for all treatments stratified by depth beneath the soil surface. Greater anaerobic score corresponds to decreased soil oxygen. Control plots exhibit greater aeration than soil beneath pavement.
Table 3. Mean anaerobic scores and standard errors during summer 2008. Significant differences resulting from treatment are noted by different symbols following the mean value. $(P=0.05)$

\begin{tabular}{lcccc}
\hline & \multicolumn{4}{c}{ Depth below ground $(\mathbf{c m})$} \\
\cline { 2 - 5 } Treatment & $\mathbf{0 - 1 2}$ & $\mathbf{1 2 - 2 4}$ & $\mathbf{2 4 - 3 6}$ & $\mathbf{3 6 - 4 8}$ \\
\hline Control & $0.15(0.22) \mathrm{a}$ & $0.55(0.82) \mathrm{a}$ & $1.70(1.87) \mathrm{a}$ & $1.15(1.42) \mathrm{a}$ \\
Porous Pavement & $5.45(1.85) \mathrm{b}$ & $6.55(2.58) \mathrm{a}$ & $6.80(2.67) \mathrm{a}$ & $6.30(2.51) \mathrm{ab}$ \\
Impervious & & & & \\
Pavement & $4.75(2.22) \mathrm{b}$ & $5.00(2.66) \mathrm{a}$ & $5.80(2.63) \mathrm{a}$ & $9.30(1.98) \mathrm{b}$ \\
\hline
\end{tabular}

tually the entire soil profile beneath paved treatments limits root function. Conversely, Watson (2006) determined that fine root density decreased consistently only when rusting occurred on less than $25 \%$ of the rod. This occurred only in deep layers [36-48 cm (14.2-18.9 in)] under impervious paving, implying that only the deepest soils beneath impervious surfaces would limit root function. This conflicting information prevents conclusions on whether soil aeration below pavements is adequate for plant function.

\section{CONCLUSION}

Soil water content beneath both pavement treatments was exceptionally high throughout the growing season, never dropping below the soil's field capacity. Also, soil aeration beneath pavements was much lower than under unpaved soils. In addition to better aeration, the soil moisture in unpaved soils was within the bounds of the LLWR. Soil moisture increased predictably with depth in the unpaved plots; however, both pavement types modified this distribution. Under impervious pavements, the wettest soil was often in the uppermost $10 \mathrm{~cm}$, while under pervious paving the deepest layer was wettest, followed by soil at $5 \mathrm{~cm}$, then $10 \mathrm{~cm}$ depth. Daily fluctuations in $\theta_{\text {soil }}$ also differed between paved and unpaved soils. Whereas unpaved soils are subject to large daily fluctuations, paved soils are buffered from change, especially under impervious paving.

The observed differences in $\theta_{\text {soil }}$ between paved and unpaved soils are likely driven by the distillation process and the buffering effects of paving. During daytime, pavements present an evaporation barrier, whilst at night, cooling surface temperatures result in upward distillation of moisture beneath paved treatments. Together, these mechanisms result in relatively high soil moisture at shallow depths beneath paving.

It was expected that the physical differences between pervious and impervious pavement would lead to differences in underlying soil moisture and aeration. However, this was generally not the case. Exceptions were better soil aeration at depths 39-45 $\mathrm{cm}$ (15.4-17.7 in) below the soil surface under pervious paving; and small, temporary increases in $\theta_{\text {sil }}$ beneath pervious pavements, the result of isolated rainfall events. However, $\theta_{\text {soil }}$ and aeration were broadly similar beneath both pavement treatments.

In summary, under the conditions of this experiment, the hypothesis that soil moisture and aeration differ beneath pervious and impervious paving is not supported. However, soil physical conditions beneath both types of paving do differ markedly from unpaved soils. If pervious paving does benefit urban trees relative to impervious paving, as alluded to by other authors, it is unlikely that the benefits arise from improved water or aeration dynamics. 
Acknowledgements. The authors would like to thank the New Zealand School of Forestry and Auckland City Council for funding. The contributions of Lachlan Kirk, Nigel Pink, Neil Smith, and Joe Cartman were greatly appreciated. Finally, the authors thank the anonymous reviewers for their recommendations.

\section{LITERATURE CITED}

Andersen, C.T., I.D.L. Foster, and C.J. Pratt. 1999. The role of urban surfaces (permeable pavements) in regulating drainage and evaporation: development of a laboratory simulation experiment. Hydrological processes 13:597-609.

Asaeda, T., and V.T. Ca. 2000. Characteristics of permeable pavement during hot summer weather and impact on the thermal environment. Building and Environment 35:363-375.

Baumhardt, R.L., R.J. Lascano, and S.R. Evett. 2000. Soil material, temperature, and salinity effects on calibration of multisensor capacitance probes. Soil Science Society of America Journal 64:1940-1946.

Brown, L.J., and J.H. Weeber. 1992. Geology of the Christchurch Urban Area. Scale $1: 25$ 000. Institute of Geological and Nuclear Sciences Limited, Lower Hutt, NZ. $104+1$ map p.

Buchan, G.D. 2001. Soil Temperature Regime. In Soil and Environmental Analysis: Physical Methods. K.A. Smith and C.E. Mullins. (Eds.) Marcel Dekker, New York, pp. 539-594.

Carnell, R., and M.A. Anderson. 1986. A technique for extensive field measurement of soil anaerobism by rusting of steel rods. Forestry 59:129-140

Celestian, S.B., and C.A. Martin. 2004. Rhizosphere, surface, and air temperature patterns at parking lots in Phoenix, Arizona, U.S. Journal of Arboriculture 30:245-252.

Cobos, D.R. 2007. Calibrating ECH $\mathrm{E}_{2} \mathrm{O}$ Soil Moisture Sensors, Application Notes Series. Decagon Devices Inc., Pullman, WA.

Decagon Devices Inc. 2006. ECH $\mathrm{O}_{2}$ Soil Moisture Sensor Operator's Manual for Models EC-20, EC-10, and EC-5 Version 5.

Feng, G., L. Wu, and J. Letey. 2002. Evaluating Aeration Criteria by Simultaneous Measurement of Oxygen Diffusion Rate and Soil Water Regime. Soil Science 167:495-503.

Ferguson, B.K. 2005. Porous Pavements. Taylor and Francis Group, New York.

Glinski, J., and W. Stepniewski. 1985. Soil Aeration and its Role for Plants. CRC Press, Boca Raton, FL. 200 pp.

Hodge, S.J., and R. Boswell. 1993. A study of the relationship between site conditions and urban tree growth. Journal of Arboriculture $19 \cdot 358-367$
Hodge, S.J., R. Boswell, and K. Knott. 1993. Development of the steel rod technique for the assessment of aeration in urban soils. Journal of Arboriculture 19:281-288.

Lane, P.N.J., and D.H. Mackenzie. 2001. Field and laboratory calibration and test of TDR and capacitance techniques for indirect measurement of soil water content. Australian Journal of Soil Research 39:1371-1386

Larcher, W. 2003. Physiological Plant Ecology: ecophysiology and stress physiology of functional groups. Springer, Berlin. 513 pp.

Letey, J. 1985. Relationship between soil physical properties and crop production. Advances in Soil Science 1:276-294.

McGann, R.P. 1983. The Climate of Christchurch Ed. M.o. Transport. New Zealand Meteorological Service.

Owens, P.R., L.P. Wilding, W.M. Miller, and R.W. Griffin. 2008. Using iron metal rods to infer oxygen status in seasonally saturated soils. Catena 72:197-203.

R Development Core Team. 2008. R: A Language and Environment for Statistical Computing. R Foundation for Statistical Computing, Vienna, Austria.

Raeside, J.D. 1974. Soil Map of Christchurch Region, New Zealand. scale 1:63,360. In: NZ Soil Survey Report 16.

Tennis, P.D., M.L. Leming, and D.J. Akers. 2004. Pervious Concrete Pavements. Portland Cement Association and the National Ready Mixed Concrete Association.

van Keulen H., and D. Hillel. 1974. A simulation study of the dryingfront phenomenon. Soil Science 118:270-273.

Watson, G. 2006. Establishing a relationship between soil aeration and fine root development of seven tree species using the steel rod technique. Arboricultural Journal 29:161-171.

Justin Morgenroth

School of Forestry

University of Canterbury

Christchurch, Private Bag 4800

New Zealand

Graeme D. Buchan

Soil \& Physical Sciences Group

Lincoln University

PO Box 84

Canterbury, Lincoln 7647

New Zealand 
Résumé. Des surfaces pavées perméables sont de plus en plus installées en milieu urbain, et ce dans le cadre de stratégies de gestion de l'eau lors de fortes pluies. Ces surfaces présentent une résistance similaire aux surfaces imperméables analogues, mais elles sont plus perméables à l'air et à l'eau. Ces caractéristiques fonctionnelles ont mené à spéculer que les surfaces perméables pourraient être, contrairement aux surfaces imperméables, bénéfiques aux arbres urbains. Partant du fait que la perméabilité à l'air et à l'eau aurait un effet direct sur le sol environnant, cet article décrit la recherche qui explore les effets des surfaces perméables sur les conditions physiques du sol sous-jacent. Les résultats indiquent qu'alors que l'humidité et l'aération du sol diffèrent grandement sous les surfaces perméables versus imperméables, ces différences sont généralement insignifiantes entre ces deux types de surfaces. Si les arbres urbains ne tirent pas de bénéfices des surfaces perméables par rapport aux surfaces imperméables, c'est donc que ce n'est sans doute pas une conséquence de l'humidité ou de l'aération du sol. Les résultats mettent donc au défis les théories existantes et contribuent à la compréhension sur le comment les surfaces perméables affectent les dynamiques de l'humidité et de l'aération des sols sous-jacents.

Zusammenfassung. Wasserdurchlässige Pflasterdecken werden zunehmend in urbanen Bereichen als eine Maßnahme zur Hochwasserbekämpfung eingebaut. Wasserdurchlässige Decken zeigen eine gleichwertige Stärke wie andere Pflasterungen, aber sind hoch durchlässig für Luft und Wasser. Diese funktionalen Eigenschaften haben zu der Spekulation geführt, dass wasserdurchlässige Decken im Gegensatz zu undurchlässigen Decken besser für Bäume sein können. Unter der Annahme, dass die Durchlässigkeit von Wasser und Luft einen direkten Effekt auf den Boden hat, beschreibt diese Studie Forschungsergebnisse zum Einfluss von durchlässigen Decken auf den darunter liegenden Boden. Die Resultate zeigen, dass, während die Bodenfeuchte und die Belüftungsdynamik unter durchlässigen und undurchlässigen Böden sehr differiert, die anderen Unterschiede allerdings nicht signifikant waren. Wenn urbane Bäume von durchlässigem Pflaster profitieren, liegt es nicht konsequenterweise an der Bodenfeuchte und Durchlüftung. Die Resultate ändern bestehende Theorien und tragen dazu bei, wie durchlässige Pflasterungen die Bodenfeuchte und Belüftung der darunter liegenden Böden beeinflusst.

Resumen. La pavimentación permeable se ha incrementado en áreas urbanas como una estrategia de manejo del agua torrencial durante las tormentas. Estos pavimentos muestran resistencia similar a otros materiales análogos, pero son altamente permeables al aire y al agua. Estas características funcionales han dado lugar a la especulación de que el pavimento permeable, usado en lugar del impermeable, podría beneficiar a los árboles. Debido a que la permeabilidad al aire y al agua tendría un efecto directo en el ambiente del suelo, este artículo describe la investigación que explora el efecto del pavimento permeable en las condiciones físicas del subsuelo. Los resultados indican que mientras la humedad del suelo y la aireación difieren grandemente debajo de las superficies pavimentadas y no pavimentadas, las diferencias son usualmente insignificantes entre el pavimento permeable y el impermeable. Si el árbol urbano se beneficia de los materiales permeables en relación a los impermeables, probablemente no es una consecuencia de la humedad y aireación del suelo. Los resultados desafían las teorías existentes y contribuyen al entendimiento de cómo los pavimentos permeables afectan las dinámicas de humedad y aireación de las capas subyacentes del suelo. 